\title{
SELECTED ISSUES OF THE MINIMUM WAGE IN THE CZECH REPUBLIC
}

\author{
Tomáš Pavelka, Marek Skála, Jan Čadil
}

\section{Introduction}

The minimum wage can be defined as the lowest possible level of remuneration that an employer can pay to an employee for his work. In the world there are basically two mechanisms of the minimum wage settings. The first is determination of the minimum wage by law (the legal regulation) and it is called the statutory minimum wage. The statutory minimum wage can be applied either to all sectors or selectively only to certain sectors. The second mechanism is the setting of minimum wages by collective agreements. They could be collective agreements at the company level or higher level collective agreements, i.e. applied to certain sectors or particular professions [2]. It is common that in addition to the basic rate of minimum wages, there are special reduced rates, such as for young workers or for persons with disabilities. Within the European Union, all Member States apply some form of minimum wages. Most of them (twenty) use the statutory minimum wage and other Member States determine the minimum wage by collective bargaining.

The minimum wage is the measure of economic policy which raises conflicting views. Opponents of the minimum wage mostly emphasize its negative impact on employment and often disagree with its social function. On the contrary, its proponents emphasize its importance in the fight against poverty, in the creation of incentives to work, in reducing the imbalances in labour relations (limiting the power of employers) or in reducing wage inequality between the bottom and middle of the income distribution [9]. Some proponents of the minimum wage also question the negative impact of minimum wages on employment and even state that, under certain conditions, the minimum wage could lead to employment growth. Finally, proponents of the minimum wage indicate that the minimum wage in today's globalized world can prevent wage and social dumping [18, p. 3].

For the first time the minimum wage was introduced in New Zealand and Australia in the 1890's. In the Australian state of Victoria, the law on minimum wage was approved in 1896, under which the labour authorities were created that defined the lowest wages for five selected "sweated" industries. One of these industries in the state of Victoria was the textile industry, in which workers often created production outside the premises of the employer (e.g. at home). The United Kingdom adopted similar law in 1909. In 1938, under the Fair Labour Standards a minimum wage was enacted in the United States. In its early days, the institute of a minimum wage was introduced as a measure for the eradication of poverty in the "sweated" industries. Gradually, however, the applicability of the minimum wages widened. E.g. Canada and New Zealand gradually increased the force of the minimum wage from some sectors to almost all industry at the beginning of the twentieth century.

Since its introduction in 1991, the minimum wage has undergone several stages of development in the Czech Republic. In some periods the minimum wage was increased, and in some periods it stagnated. This uneven development has had an impact on the labour market. One of the objectives of this article is to describe the development of the institute of the minimum wage in the Czech Republic. Attention will be given not only to the gross nominal minimum wage, but also the development of the real and the net minimum wage. The second objective of the article is to assess whether the minimum wage fulfills its motivational function, i.e. if it pays for people to work or if it is better to live on social benefits. The final part of the article is devoted to an analysis of the impact of changes in the minimum wage on unemployment in the Czech Republic. In addition to the impact of changes in minimum wages on total 
unemployment, the impact of unemployment of young people and people with disabilities will also be examined.

\section{The Minimum Wage in Professional Literature}

Considerable attention is devoted to the minimum wage in world literature. The first scholarly articles appeared shortly after the first introduction of a minimum wage in the 19th and 20th century. The extending of the minimum wage in the United States gave further impetus to the scientific literature. From the beginning, economists' views on the minimum wage have differed. As Leonard says in his article, the main proponents of the minimum wage were then prominent economists such as Ely, Commons, Henry Rogers Seager, Sidney Webb and John B. Andrews. In contrast, the opponents of the minimum wage were Alfred Marshall, John Bates Clark, Frank Taussig, Phillip Wickteed and A. C. Pigou [10, p. 699]. Opponents of the minimum wage have come from assumptions of neoclassical economics, which show that the increase in the minimum wage must necessarily lead to a decline in employment [13, p. 7]. British economist Sydney Webb refused this simple neoclassical model and pointed out the relationship between the minimum wage and labour productivity of recipients of the minimum wage [19, p. 983]. In Webb's approach can be found common features with the theory of efficiency wages, which is a part of the new Keynesian economics [16, p. 288]. In 1940's, George Stigler and Richard Allen Lester were the key participants of a dispute regarding the impact of the minimum wages on employment. Stigler, on the basis of neoclassical approach, concluded that a stronger increase in employment cannot be achieved by legislation, and the introduction of the minimum wage always causes, in his opinion, growth of unemployment $[1$, p. 360]. Lester on the contrary, did not see the minimum wage as a key factor of reducing employment: "Market demand is more important than the wage rates in determining the amount of employment in the company" [11, p. 81]. In the following period, it seemed that a certain consensus that the minimum wage has a negative impact on employment had been achieved among economists. The article by Charles Brown, Curtis Gilroy and Andrew Kohen from 1982 provides an overview of scientific papers from this period. The article by Card and Krueger from 1994, entitled "Minimum Wage and Employment: A Case Study of the FastFood Industry in New Jersey and Pennsylvania," significantly enhanced expert debate on the impact of minimum wages on employment. In this article, the authors compared the impact of an increase in the minimum wage on employment in fast-food restaurants. In 1992 there was an increase in the minimum wage in the State of New Jersey, while in neighboring Pennsylvania, the minimum wage had not changed. The authors concluded that they had found no evidence that increasing the minimum wage in New Jersey reduced employment in fast-food restaurants in this state in comparison with Pennsylvania [4, p. 792]. Both authors carried out further studies, which show that the minimum wage had a positive impact on employment [5, pp. 389-390]. Neumark and Wascher in his book Minimum Wage criticized the results of studies by Card and Krueger and stated that their own studies as well as studies of other authors clearly confirm the negative impact of minimum wages on employment [14, p. 104].

In Czech literature, the majority of scientific texts are particularly devoted to the description of the minimum wage and to a limited extent, more detailed econometric analysis of the impact of minimum wages on the labour market and wage differentiation can be found. One of the reasons is the unavailability of data and the relatively short time series. In this context it should be noted that the minimum wage, as discussed below, remained unchanged from 2007 until August 2013, which essentially prevents a recent econometric estimate of the impact of minimum wages on employment. For a long time, Baštýr focused his attention on the issue of minimum wage in the Czech Republic. For example in his study he argued against discussed possibility of differentiating the minimum wage in the Czech Republic by region [2, p. 12]. In another study, on the contrary, Baštýr urged a debate over the minimum wage differentiation within the higher level collective agreements [1]. The study by Gottwald et al. analysing the evolution of minimum wages in 1998-2000 concluded that the impact of the minimum wage on Czech labour market is low and insignificant [8]. Fialová tried to verify, with data 1991-2003, if the growth of the minimum 


\section{Ekonomie}

wage increased employment and total income of poor households. According to the author, the increase of the minimum wage in this period did not lead to an increase in labour income of poor households, and even in the case of the total income, the minimum wage did not significantly contribute to its increase. Fialová also concluded that the increase of share of the minimum wage to average wage had a significant impact on the increase in unemployment in the regions. However, as the author herself stated, estimates of the elasticity are not very robust because they are sensitive to the inclusion of particular variables [7, p. 29]. A similar negative impact of increasing the minimum wage on unemployment in the region found in his article Fialová and Mysíková. According to the authors, if the share of minimum wage to the average wage in the region increases by $1 \%$, the unemployment rate will increase by 0.3 to $0.7 \%$. Estimates of elasticities, however, were again not too robust [6].

\section{The Minimum Wage in Czechoslovakia and the Czech Republic}

\section{The Minimum Wage before 1989}

The institute of the minimum wage began to expand in Europe at the beginning of the last century. Decrees of the Minister of trade, warfare and welfare of the Austro-Hungarian Empire about wages for sewing textile goods by order of the army, which were amended several times, represents the first forms of minimum wage at the Czech territory. Under these regulations, the minimum wage depended on the type of clothing and also on the place of work. Independent Czechoslovakia did not establish a minimum wage, which would cover all employees. However, shortly after the establishment of an independent state, several proposals to introduce a general or at least a professional minimum wage was submitted. One of the proposals to the National Assembly in January 1919 was submitted by Member of Parliament Mečir and his colleagues, which pointed out that the foundation of Czechoslovakia would not only be freedom but social justice as well. In response to the poor living conditions of home workers (i.e. that which worked outside the premises of the employer), in September 1919, the National Assembly passed the law which was prepared by Minister for Social Welfare Dr. Winter [21]. In the preamble to the Act, Dr. Winter said that there was a decline in wages as part of the price undercutting at home workers sector. On the basis of the Act, central committees were formed, whose main task was to determine wage rates. In the newly created Czechoslovakia a minimum wage was only established for home workers.

After the World War II, the minimum wage in Czechoslovakia did not exist, despite the fact that the Czechoslovak Socialist Republic ratified the Conventions of International Labour Organization on the minimum wage. Convention No. 26: Minimum Wage-Fixing Machinery Convention was ratified by Czechoslovakia on the 12th June 1950 and Convention No. 99: Minimum Wage Fixing Machinery (Agriculture) Convention on 21st January 1964. Conventions no. 26 and 99 was ratified by independent Czech Republic on the 1st January 1993. The third Convention of the International Labour Organization No. 131: Minimum Wage Fixing Convention, from 1970 was not ratified by Czechoslovakia and then the independent Czech Republic.

\section{The Minimum Wage after 1989}

The minimum wage was introduced in Czechoslovakia in 1991. The current minimum wage is regulated by $\S 111$ of Act No. 262/2006 Coll., The Labour Code, as amended and Government Decree No 567/2006 Coll. stipulating minimum wage rates and premiums for work under dangerous conditions and for work at night, as amended. According to the Labour Code, the minimum wage is "... the lowest permissible level of remuneration in employment relationship..." [20, § 111]. It is obvious that the minimum wage is not valid only for traditional employment contracts in the business or nonbusiness sector, but also for relations based on agreement to complete a job or on agreement to perform certain work. In organizations in which collective bargaining on wages is carried out, the minimum wage may be fixed at a higher level than the statutory minimum wage. In the case of such organizations in which collective bargaining on wages does not take place in determining the amount of the minimum wage or remuneration agreements, a guaranteed level of wages is applied in addition to the 
minimum wage. In non-business organizations in which employees are salaried, in addition to the minimum wage and guaranteed levels of wages, a system of wage tariffs are applied [20, $\S 112]$.

Since the introduction of the minimum wage in 1991, there were 16 amendments of its amount. Monthly and hourly rates of nominal gross minimum wages are shown in Table 1 . Three periods of development of the minimum wage in the Czech Republic can be described since 1991.

The first period is bounded by the years 1991 and 1998. Within this period, the minimum wage was increased four times. The monthly minimum wage increased from 2,000 to $2,650 \mathrm{CZK}$, i.e. $650 \mathrm{CZK}$ or $32.5 \%$. The average annual rate of increase in the minimum wage was $3.6 \%$ in this period. Increases in the minimum wage during this period can be described as very low with respect to the price level and the average wage. The significance of the minimum wage, in particular of its social role, declined during this period. Explanation of relatively low growth of the minimum wage in the first period is associated with the political orientation of the then Czech government. Right-wing conservative governments are mostly sceptical of the institute of the minimum wage. The minimum wage is understood as a distortion of the market mechanism for setting wages, which is associated with rising unemployment.

The second period can be defined from 1999 to 2006. It was a period during which there were regular increases in the minimum wage, usually with effect from 1 January of the year (there were also increases in the minimum wage from July of 1999, 2000 and 2006). The total monthly nominal wage increased by 5,305 CZK between 1999 and 2006, i.e. an increase of more than $200 \%$. When adjusted for one year, the average growth rate of nominal minimum wage was about $14.7 \%$, which was more than 11 percentage points more compared to the first period. The second period is characterized by a leftist orientation of Czech governments (with the exception of the government of Prime Minister Tošovský). The raising minimum wage led again to a renewal its social and motivational functions. In the previous period, the minimum wage had fallen below the living minimum of independently living individuals, thus the motivation to look for a job or keep a job was reduced. The gradual increase in the minimum wage reversed this negative development. The importance of the minimum wage in the second period is evident from the fact that the minimum wage was mentioned in the program declarations of governments during this period, when the Czech government also adopted the Social Charter of the Council of Europe, which also includes the right to remuneration ensuring a decent standard of living for workers and their families.

The third period is the period between 2007 and 2012. In January 2007, the monthly nominal minimum wage was increased by 55 CZK up to 8,000 CZK. The Czech government did not increase the nominal minimum wage for more than five years, which was unique within the European Union. The motivational and social function of the minimum wage gradually decreased during this period.

Lastly, the monthly minimum wage was increased by $500 \mathrm{CZK}$ or by $6.25 \%$ from August 2013. It seems that a new period of development of the minimum wage begins from that year, as the newly created government declared its intention to further increase the minimum wage.

In addition to the basic minimum wage, reduced rates for young employees and employees who are eligible for disability retirement existed until the end of 2012. Since January 2013 these reduced rates were revoked and there was only a basic minimum wage. Reduced rates were applied due to the lower labour productivity of listed groups. The cancellation of reduced rates of minimum wages reflected the desire for equal status of persons with disabilities and youth in remuneration. Low willingness of employers to employ people with disabilities has led to the fact that the minimum wage for people with disabilities has not changed since August 2013. Or, in other words, there is a reduced rate for people with disabilities $(8,000 \mathrm{CZK})$ in addition to the basic rate of minimum wages $(8,500 \mathrm{CZK})$ again now. 


\section{Ekonomie}

Tab. 1: The development of the gross nominal minimum wage in the Czech Republic

\begin{tabular}{l|l|c|c}
\multicolumn{2}{l|}{$\begin{array}{c}\text { Valid from } \\
\text { (the 1st day of month) }\end{array}$} & $\begin{array}{c}\text { Monthly minimum wage } \\
\text { (CZK) }\end{array}$ & $\begin{array}{c}\text { Hourly minimum wage } \\
\text { (CZK) }\end{array}$ \\
\hline 1991 & February & 2,000 & 10.80 \\
\hline 1992 & January & 2,200 & 12.00 \\
\hline 1996 & January & 2,500 & 13.60 \\
\hline 1998 & January & 2,650 & 14.80 \\
\hline 1999 & January & 3,250 & 18.00 \\
\hline & July & 3,600 & 20.00 \\
\hline 2000 & January & 4,000 & 22.30 \\
\hline & July & 4,500 & 25.00 \\
\hline 2001 & January & 5,000 & 30.00 \\
\hline 2002 & January & 5,700 & 33.90 \\
\hline 2003 & January & 6,200 & 36.90 \\
\hline 2004 & January & 6,700 & 39.60 \\
\hline 2005 & January & 7,185 & 42.50 \\
\hline 2006 & January & 7,570 & 44.70 \\
\hline & July & 7,955 & 48.10 \\
\hline 2007 & January & 8,000 & 48.10 \\
\hline 2013 & August & 8,500 & 50.60 \\
\hline
\end{tabular}

\section{Trends in the Minimum Wage in the Czech Republic and Its Relation to Some Socio-Economic Variables}

\section{Development of the Nominal and Real Minimum Wage}

In addition to the development of nominal wage, it is necessary to consider also the development of its purchasing power. Figure 1 shows the development of real minimum wage.

The starting amount of the monthly minimum wage was set to $2,000 \mathrm{CZK}$ in 1991. During the first period (1991-1998) the government increased it in only three years: $1992(10 \%)$, 1996 (13.6\%) and 1998 (6\%). However, the price level increased annually, with the highest increase of $20.8 \%$ in 1993 thanks to the effect of the value added tax introduction. In the other years of the first period, the inflation rate ranged from 8 to $11 \%$. The first period is therefore possible to characterize by the decrease in purchasing power of the minimum wage (except for 1996). It is evident that the social function of the minimum wage during this period decreased gradually. In 1998, the minimum wage amounted to only $63 \%$ of its purchasing power in 1991.

The second period, between 1999 and 2006, is characterized by rapid increases in monthly minimum wage. The minimum wage increased every year and in three years (1999, 2000,2006 ) even twice a year. Overall, the growth in minimum wage exceeded the price level in this period and the government managed to eliminate the decline in real minimum wage in the previous period. The nominal minimum wage in this period increased on average by $14.7 \%$, while the average annual increase in the price level was only about $2.5 \%$. With the rapid growth of the nominal minimum wage its real value gradually increased and in 2006 reached $156 \%$ of its value from 1991 .

The third period, 2007-2012, is characterized by a decline in the real minimum wage. The government raised the monthly nominal minimum wage only by $0.56 \%$ (or by $55 \mathrm{CZK}$ ) in year 2007. In the remaining years, the 
nominal minimum wage remained unchanged and amounted to $8,000 \mathrm{CZK}$. The average annual increase in the price level in the third period was $2.8 \%$. The largest decline in the real minimum wage was in $2008(-5.9 \%)$, when the price level rose quickly, by $6.3 \%$, due to some measures taken in connection with the reform of public finances (an increase of reduced VAT rate from $5 \%$ to $9 \%$ and the introduction of regulatory health care fees) and due to the increase in food prices and regulated energy prices. Therefore, there was an increase in prices, especially those items of the consumer basket, which are dominant in the spending of low wage earners, in which recipients of the minimum wage can be included. During the third period, the purchasing power of the minimum wage gradually decreased, and in 2012 it amounted to only $137 \%$ of its value in 1991 .

\section{Fig. 1: Real changes of the minimum wage in the Czech Republic}

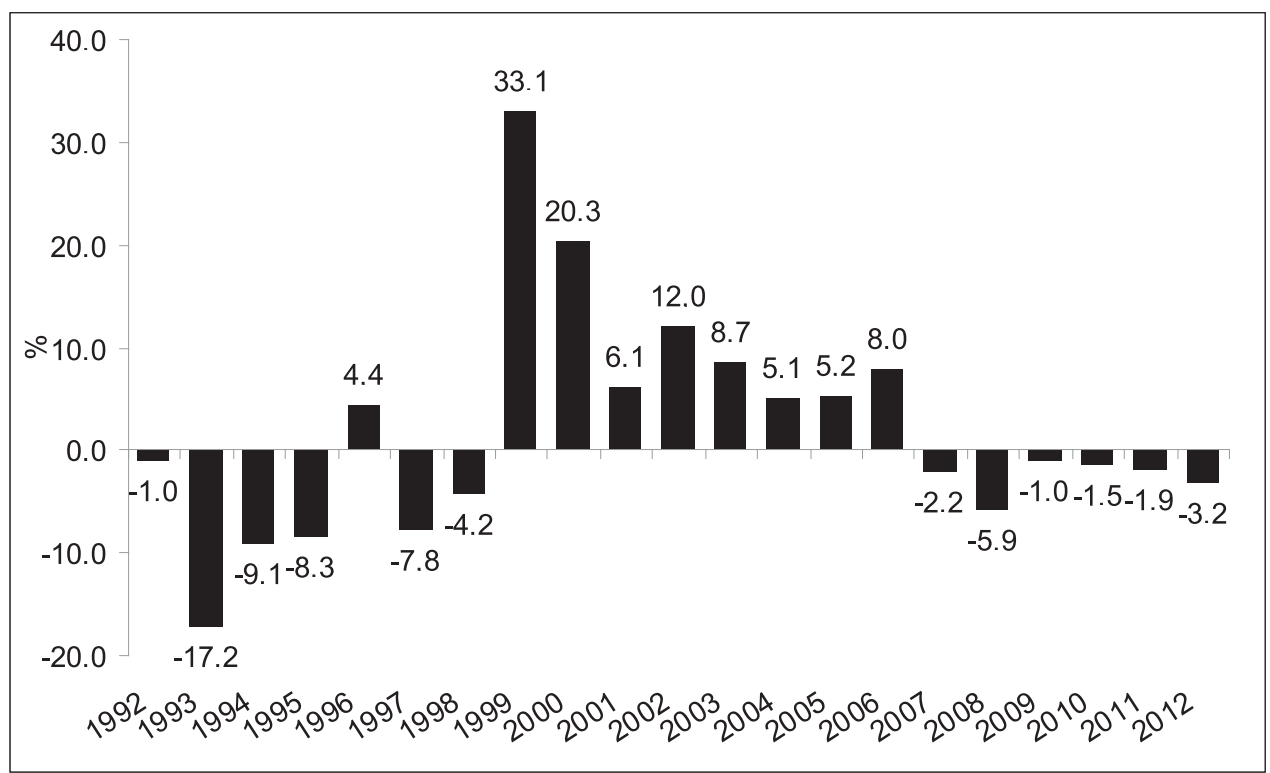

Source: own calculation

\section{Gross and Net Minimum Wage}

Besides the development of the price level, the amount of goods and services that the minimum wage beneficiary can obtain for it is also influenced by developments in the field of taxation. The actual tax rate, the amount of deductibles and development of rates of health and social insurance play their role. Social security contributions paid by employees include sickness insurance, pension insurance and contribution to the state employment policy. Household composition also has a significant impact on the net minimum wage. A number of model cases for further analysis can be found, however, in this paper two cases will be used. The first case will be an employee who is unmarried and has no dependent children. The second case is a single employee with one dependent child. It can be assumed that the typical recipient of the minimum wage will be represented by one of these cases.

Until 1992 there was only the payroll tax, which was regulated by Law No. 76/1952 Coll [22]. For employees without children and with one child, the standard rate was increased by $60 \%$. In 1993 there was a tax reform, under which a progressive personal income tax ( 6 bands from $15 \%$ to $47 \%$ ) was introduced and a system of tax deductible items (among others for a taxpayer and for a child) was introduced 


\section{Ekonomie}

too. Due to the tax reform, the only decline in net minimum wage occurred in 1993. For employees without dependent children the net minimum wage decreased by $2 \%$ and for the employees with one dependent child by $0.5 \%$. The existence of child allowance was a cause of a lower decrease in the net minimum wage for employees with one child. In the following years, there were increases in the basic allowance for the taxpayer and the child allowance and also decreases in the total insurance rates paid by employees. Because of these, the net minimum wage increased more than the gross minimum wage.

In 2005 there was a significant change: child allowance was exchanged for a child credit, in the amount of 6,000 CZK per year.
Tax credits are deducted directly from the calculated tax, not from the tax base as in the case of deductible items in previous years. Moreover, if the tax credit exceeds the tax liability of the taxpayer, there is a tax bonus for which taxpayer can apply for under the conditions set by law. In 2006, the tax credit directly for the taxpayer itself was established. In this case, however, there is no tax bonus. Tax credits on the taxpayer's and especially per child were increased in some subsequent years, which led to the growth of the net minimum wage even in years in which the gross minimum wage did not change. It is worth mentioning that since 2008 , so-called super gross wage and credits per taxpayer and child have been introduced, thus again the minimum wage in the net increased.

\section{Tab. 2: The gross and net minimum wage in the Czech Republic}

\begin{tabular}{|c|c|c|c|}
\hline & $\begin{array}{c}\text { Gross minimum } \\
\text { wage }\end{array}$ & $\begin{array}{c}\text { Net minimum wage } \\
\text { of employee without child }\end{array}$ & $\begin{array}{l}\text { Net minimum wage of } \\
\text { employee with one child }\end{array}$ \\
\hline 1991 & 2,000 & 1,597 & 1,597 \\
\hline 1992 & 2,200 & 1,912 & 1,912 \\
\hline 1993 & 2,200 & 1,873 & 1,903 \\
\hline 1994 & 2,200 & 1,888 & 1,903 \\
\hline 1995 & 2,200 & 1,909 & 1,909 \\
\hline 1996 & 2,500 & 2,187 & 2,187 \\
\hline 1997 & 2,500 & 2,187 & 2,187 \\
\hline 1998 & 2,650 & 2,318 & 2,318 \\
\hline 1999 & 3,600 & 3,114 & 3,150 \\
\hline 2000 & 4,500 & 3,782 & 3,938 \\
\hline 2001 & 5,000 & 4,194 & 4,375 \\
\hline 2002 & 5,700 & 4,715 & 4,988 \\
\hline 2003 & 6,200 & 5,087 & 5,381 \\
\hline 2004 & 6,700 & 5,458 & 5,778 \\
\hline 2005 & 7,185 & 5,818 & 6,319 \\
\hline 2006 & 7,955 & 6,725 & 7,225 \\
\hline 2007 & 8,000 & 6,760 & 7,260 \\
\hline 2008 & 8,000 & 7,000 & 7,890 \\
\hline 2009 & 8,000 & 7,120 & 8,010 \\
\hline 2010 & 8,000 & 7,120 & 8,087 \\
\hline 2011 & 8,000 & 7,120 & 8,087 \\
\hline 2012 & 8,000 & 7,120 & 8,237 \\
\hline 2013 (August) & 8,500 & 7,565 & 8,682 \\
\hline
\end{tabular}


The gross monthly minimum wage did not change from 2007 to 2012 and was 8,000 CZK. In the case of an employee without dependent children, the net monthly minimum wage did not change in the period 2009-2012 and was $7,120 \mathrm{CZK}$. In the case of employee with one dependent child, the net monthly minimum wage increased to $8,237 \mathrm{CZK}$ in 2012, which was more than the gross monthly minimum wage. This particular "paradox" was caused by the existence of a tax bonus for child. The increase in gross minimum wage in August 2013 led to a corresponding increase in the net minimum wage as well.

From the calculated values in the Table 2 it is clear that in the year of the minimum wage introduction, beneficiaries of the minimum wage pay about $20 \%$ of their wage in the form of tax and insurance. In the following years, the share of net to gross minimum wage increased and stabilized at $86-87.5 \%$. Since 1999 , however, in the case of an employee without dependent children, this share began to decline and reached its lowest level in 2005, when the net minimum wage was only $81 \%$ of the gross minimum wage. For the employee with one child, the share of net minimum wage to gross minimum wage, with the exception of a slight decline in the years 2003-2004, remained basically unchanged and amounted to about $87.5 \%$ till 2005. In 2008-2012, there was no change of gross monthly minimum wage, but in the case of employee with one dependent child, the proportion of the net minimum wage to the gross minimum wage increased due to adjustments in taxation and insurance. In 2009, the net minimum wage exceeded the gross minimum wage in the case of employee with one dependent child, which was due to the existence of the tax bonus per child. Since August 2013, the share of the net minimum wage to gross minimum wage for an employee with one dependent child is $102 \%$. An employee without a dependent child pays $11 \%$ of their gross salary in the form of income tax and insurance since August 2013.

\section{Motivational Function of the Minimum Wage}

To assess whether the minimum wage is set up to encourage the recipient to work, or at least to seek employment, the net minimum wage is very often compared to the living minimum. In order to fulfil its motivational function, the net minimum wage must be sufficiently higher than the living minimum. Only slightly higher minimum wage than the living minimum is not sufficient to ensure that the recipient will look for a job or be willing to keep a current job. Jobs are related to some other costs that cannot be essentially aggregately quantified, such as the cost of transport to job, loss of leisure time value, etc. In this context, it is necessary to mention that the living minimum included the amount needed to sustenance and other basic personal needs and the amount needed to cover necessary expenses connected with housing. Since 2007, however, an amount necessary to cover the cost of housing is not a part of the living minimum. These costs are included in the housing allowance. In the analysis, a variety of model situations can be used. The living minimum is affected by the number of people in the household and by the age of children. Also, the housing allowance depends on the number of people in the household and on the age of children, but in addition also on whether the household lives in a rental or cooperative (or own) flat, and also on the size of the city.

The Table 3 shows how the net minimum wage deviates from the living minimum plus the housing allowance for an employee without dependent children and for an employee with one dependent child aged 10 to 15 years. The situations when the household lives in Prague or in a small town up to 9,999 inhabitants are compared. Note: For more details with general wage developments in the regions deals Zdeněk et al [23]. The cases when the household has a rental flat, a cooperative flat, or their own flat are compared in both situations (In the model cases, it is not taken into account that the housing allowance is provided for a maximum).

From the Table 3 it is obvious that in the case of a household without a dependent child the living minimum exceeded the net minimum wage since the introduction of the minimum wage in 1991 until 1999. In this period there was no difference between households living in Prague and in a small town, or between rental and cooperative flat. The rapid increase of the gross minimum wage between 1999 and 2006 and the partial adjustment of the tax on personal income and insurance led to the fact that the motivation to look for a job gradually 


\section{Ekonomie}

strengthened in the case of households with no dependent children. The stagnation of the gross minimum wage and the slight impact of tax and insurance adjustments on the net minimum wage in the following years, associated with the rapidly growing housing allowance, led to a gradual decline in excess of the net minimum wage against the living minimum, which was increased by a housing allowance for single households without dependent children. In the case of a person living in a rental flat in Prague, the living minimum plus housing allowance has exceeded the net minimum wage since 2010. In this situation, an employee without dependent children and living in a rental flat in Prague who receives or would have received a minimum wage would gradually lose the motivation to maintain his job or to find a new job. If a person without dependent children lived in a small town or in a cooperative or a private flat in Prague, the net minimum wage has been exceeding the living minimum (including housing allowance) for long term. Since 2006, however, this surplus has been gradually decreasing. The increase in the gross minimum wage from August 2013 slightly heightened the motivation to seek a job in the case of individuals without dependent children in a small town.

\section{Tab. 3: A comparison of the net minimum wage and the living minimum (including housing allowance)}

\begin{tabular}{|c|c|c|c|c|c|c|c|c|}
\hline & \multicolumn{4}{|c|}{ Employee without child } & \multicolumn{4}{|c|}{ Employee + child (10 to 15 years) } \\
\hline & \multicolumn{2}{|c|}{ rental flats } & \multicolumn{2}{|c|}{ co-op., own flat } & \multicolumn{2}{|c|}{ rental flats } & \multicolumn{2}{|c|}{ co-op., own flat } \\
\hline & Prague & $\begin{array}{c}\text { less than } \\
9,999 \text { inhab. }\end{array}$ & Prague & $\begin{array}{c}\text { less than } \\
9,999 \text { inhab. }\end{array}$ & Prague & $\begin{array}{c}\text { less than } \\
9,999 \text { inhab. }\end{array}$ & Prague & $\begin{array}{c}\text { less than } \\
9,999 \text { inhab. }\end{array}$ \\
\hline 1991 & -103 & -103 & -103 & -103 & $-1,303$ & $-1,303$ & $-1,303$ & $-1,303$ \\
\hline 1992 & 212 & 212 & 212 & 212 & -988 & -988 & -988 & $-988 c$ \\
\hline 1993 & -87 & -87 & -87 & -87 & $-1,417$ & $-1,417$ & $-1,417$ & $-1,417$ \\
\hline 1994 & -272 & -272 & -272 & -272 & $-1,757$ & $-1,757$ & $-1,757$ & $-1,757$ \\
\hline 1995 & -531 & -531 & -531 & -531 & $-2,151$ & $-2,151$ & $-2,151$ & $-2,151$ \\
\hline 1996 & -703 & -703 & -703 & -703 & $-2,553$ & $-2,553$ & $-2,553$ & $-2,553$ \\
\hline 1997 & -853 & -853 & -853 & -853 & $-2,793$ & $-2,793$ & $-2,793$ & $-2,793$ \\
\hline 1998 & $-1,112$ & $-1,112$ & $-1,112$ & $-1,112$ & $-3,162$ & $-3,162$ & $-3,162$ & $-3,162$ \\
\hline 1999 & -316 & -316 & -316 & -316 & $-2,330$ & $-2,330$ & $-2,330$ & $-2,330$ \\
\hline 2000 & 12 & 12 & 12 & 12 & $-1,942$ & $-1,942$ & $-1,942$ & $-1,942$ \\
\hline 2001 & 94 & 94 & 94 & 94 & $-1,955$ & $-1,955$ & $-1,955$ & $-1,955$ \\
\hline 2002 & 615 & 615 & 615 & 615 & $-1,342$ & $-1,342$ & $-1,342$ & $-1,342$ \\
\hline 2003 & 987 & 987 & 987 & 987 & -949 & -949 & -949 & -949 \\
\hline 2004 & 1,358 & 1,358 & 1,358 & 1,358 & -552 & -552 & -552 & -552 \\
\hline 2005 & 1,518 & 1,518 & 1,518 & 1,518 & -251 & -251 & -251 & -251 \\
\hline 2006 & 2,305 & 2,305 & 2,305 & 2,305 & 495 & 495 & 495 & 495 \\
\hline 2007 & 1,389 & 2,112 & 2,492 & 2,336 & -812 & 232 & 752 & 510 \\
\hline 2008 & 786 & 2,065 & 2,315 & 2,159 & $-1,347$ & 374 & 689 & 447 \\
\hline 2009 & 0 & 1,767 & 1,979 & 1,823 & $-2,516$ & -125 & 145 & -97 \\
\hline 2010 & -789 & 916 & 1,732 & 1,576 & $-3,558$ & $-1,244$ & -121 & -363 \\
\hline 2011 & $-1,275$ & 639 & 1,365 & 1,209 & $-4,242$ & $-1,651$ & -643 & -885 \\
\hline 2012 & $-2,165$ & 354 & 850 & 680 & $-5,339$ & $-1,923$ & $-1,237$ & $-1,501$ \\
\hline 2013 & $-2,311$ & 513 & 782 & 782 & $-5,764$ & $-1,900$ & $-1,571$ & $-1,571$ \\
\hline
\end{tabular}


In the case of a two-person household with one dependent child aged 10 to 15 years, the net minimum wage was only higher than the living minimum plus housing allowance for all considered situations in 2006, and in some situations in 2007-2009. This was mainly due to the adjustment of tax credits and the partial adjustment of insurance rates. In all other years, it is clear that for two-person households in which one dependent child is aged 10 to 15 years, the setting of the minimum wage demotivated people from finding a new job or keeping a current job.

\section{Impact of the Minimum Wage on Unemployment}

Considerable attention to the impact of the minimum wage on employment and unemployment is devoted in the world and partly in the Czech professional literature as well. Empirical studies do not provide clear conclusions. In the Czech Republic, the analysis of the impact of the minimum wage on unemployment is additionally complicated by the fact that the minimum wage was not changed for a relatively long period. In spite of this limitation, a statistical analysis of the impact of raising the minimum wage on the unemployment rate will be made in this part. In addition to the impact of a rise of the minimum wage on overall unemployment, the impact on young people and people with low levels of education, who are more likely to receive the minimum wage, will be examined as well. Overall unemployment is perceived as unemployment of labour force aged 15 to 64 years in this article. Youth unemployment will be examined in the group aged 15-24 years and unemployment among people with low education will be examined in the group of people with education levels 0-2 (according to ISCED-97; ISCED 0 Pre-primary education, ISCED 1 - Primary education and ISCED 2 - Lower secondary education).

For testing in all three cases a simple linear model of the dependency of the unemployment rate on the minimum wage cannot be used. First the data are partly non-stationary of degree 1 according to standard ADF test. The only variable which is $I(0)$ is the nominal wage. Using the first differences in logarithms for these variables would solve this problem. Second the unemployment rate (and its dynamics as well) is highly dependent on other factors, especially on the real output growth. This variable must be included in the model to control for this dependency. Moreover there is no strong collinearity between the growth of minimum wages and output growth which allows us to include both variables simultaneously. Third we found strong autocorrelation of unemployment growth rate at first lag which means we should include a lagged unemployment rate growth term in our estimate. Fourth for all three cases which were analyzed residuals were autocorrelated when the LM serial correlation test was applied. We therefore decided to add the $A R(1)$ term for residuals as well for the final model.

Generally, the final semi-growth LVAR model to be estimated can be expressed by the equation:

$$
\begin{gathered}
d \log \left(u_{t}\right)=b_{0}+b_{1} \log \left(m w_{t}\right)+b_{2} d \log \left(u_{t-1}\right)+b_{3} d \log \left(y_{t}\right)+\varepsilon_{t} \\
\varepsilon_{t}=\rho \varepsilon_{t-1}+\mu_{t}
\end{gathered}
$$

Where $u_{t}$ - is the unemployment rate in a given quarter, $M W_{t}-$ is the nominal minimum wage in a given quarter, $u_{t-1}-$ is the unemployment rate in the previous quarter, $y_{t}$ is GDP in constant (2005) prices in a given quarter and $c-$ is a level constant. The differences of logarithms approximate growth rates, residuals contain the $A R(1)$ process.

To analyze the dependence between the dynamics of unemployment and minimum wage, yearly growth rates for 1998-2011 on quarterly basis are used. Data for the unemployment rate come from the Labour Force survey, which is published by Eurostat. UTOT stands for the case of the total unemployment rate, U15 for the unemployment rate of young people in age 15-24 and UEDU for the unemployment rate of people with low education.

\section{The Minimum Wage and Overall Unemployment}

The results of the statistical analysis of the relationship between growth in the minimum wage and growth in the overall unemployment rate are presented in table 4 . We clearly see that the minimum wage is statistically insignificant which means, that raising the minimum wage has no effect on growth of unemployment rate in the Czech Republic. On the other hand the 


\section{Ekonomie}

link between unemployment and output growth is quite accepted by conventional wisdom - output acceleration leads to lower unemployment. Moreover we see that unemployment is autocorrelated as assumed which means that higher unemployment dynamics leads to higher dynamics in the future which is again in line with standard economic theory (hysteresis and two-way causality between unemployment and output growth).

\section{Tab. 4: Estimation of equation no. 1 for the relation between the minimum wage and the total unemployment rate}

Dependent Variable: DLOG(UTOT,0,4)

Method: Least Squares

Sample (adjusted): 1999Q3 2011Q4

Included observations: 50 after adjustments

Convergence achieved after 12 iterations

\begin{tabular}{lllll}
\hline Variable & Coefficient & Std. Error & t-Statistic & Prob. \\
\hline LOG(MW) & -0.027501 & 0.120822 & -0.227619 & 0.8210 \\
DLOG (Y,0,4) & -0.029850 & 0.006329 & -4.716373 & 0.0000 \\
DLOG(UTOT(-1),0,4) & 0.584211 & 0.104015 & 5.616578 & 0.0000 \\
C & 0.322263 & 1.071148 & 0.300858 & 0.7649 \\
AR(1) & 0.737435 & 0.140827 & 5.236452 & 0.0000 \\
\hline R-squared & & & & \\
Adjusted R-squared & 0.936806 & Mean dependent var & -0.010425 \\
S.E. of regression & 0.047785 & S.D. dependent var & 0.190087 \\
Sum squared resid & 0.102752 & Akaike info criterion & -3.149585 \\
Log likelihood & 83.73962 & Schwarz criterion & -2.958382 \\
F-statistic & 182.5989 & Hannan-Quinn criter. & -3.076774 \\
Prob(F-statistic) & 0.000000 & Durbin-Watson stat & 2.206213 \\
\hline
\end{tabular}

The Minimum Wage and Unemployment of Young People

The results of the statistical analysis of the relationship between growth in the minimum wage and growth in the rate of unemployment among young people are presented in the table 5 .
From our results it appears again that there is no significant effect of the minimum wage on the unemployment dynamics of this group. Regarding the other explanatory variables, we see a higher effect of output growth on unemployment and only a very slightly lower 
effect of lagged growth in the unemployment rate. We may conclude that this group is more sensitive to changes in economic performance, i.e. recession will harm this group more than others.

Tab. 5:

Estimation of equation no. 1 for the relation between the minimum wage and the unemployment rate of young people

Dependent Variable: DLOG(U15,0,4)

Method: Least Squares

Sample (adjusted): 1999Q3 2011Q4

Included observations: 50 after adjustments

Convergence achieved after 12 iterations

\begin{tabular}{lllll}
\hline Variable & Coefficient & Std. Error & t-Statistic & Prob. \\
\hline LOG(MW) & -0.027322 & 0.119208 & -0.229195 & 0.8198 \\
DLOG (Y,0,4) & -0.036865 & 0.009486 & -3.886292 & 0.0003 \\
DLOG(U15(-1),0,4) & 0.533803 & 0.138654 & 3.849894 & 0.0004 \\
C & 0.359999 & 1.057875 & 0.340303 & 0.7352 \\
AR(1) & 0.582046 & 0.192816 & 3.018669 & 0.0042 \\
& & & & \\
R-squared & 0.905532 & Mean dependent var & 0.009570 \\
Adjusted R-squared & 0.897134 & S.D. dependent var & 0.237114 \\
S.E. of regression & 0.076049 & Akaike info criterion & -2.220241 \\
Sum squared resid & 0.260254 & Schwarz criterion & -2.029039 \\
Log likelihood & 60.50603 & Hannan-Quinn criter. & -2.147430 \\
F-statistic & 107.8375 & Durbin-Watson stat & 2.087417 \\
Prob(F-statistic) & 0.000000 & & \\
\hline
\end{tabular}

The Minimum Wage and Unemployment of People with Low Levels of Education

The results of the statistical analysis of the relationship between growth in the minimum wage and growth in the unemployment rate of people with low levels of education are in the Table 6. It is obvious that again the impact of the minimum wage on unemployment is insignificant. From the other variables' point of view, we see that this group of people is less sensitive to changes in output growth than others, but there is still a negative relation between output growth and unemployment dynamics. On the other hand, we see high dependency on lagged values of unemployment. This can be explained by the higher probability of these people to stay unemployed for a longer time their hysteresis is probably higher than in other groups. 


\section{Ekonomie}

Tab. 6:

Estimation of equation no. 1 for the relation between the minimum wage and the unemployment rate of persons with low levels of education

Dependent Variable: DLOG(UEDU,0,4)

Method: Least Squares

Sample (adjusted): 1999Q3 2011Q4

Included observations: 50 after adjustments

Convergence achieved after 7 iterations

\begin{tabular}{lcccc}
\hline Variable & Coefficient & Std. Error & t-Statistic & Prob. \\
\hline LOG(MW) & -0.024914 & 0.057641 & -0.432224 & 0.6676 \\
DLOG (Y,0,4) & -0.016220 & 0.004701 & -3.450343 & 0.0012 \\
DLOG(UEDU(-1),0,4) & 0.614742 & 0.142450 & 4.315490 & 0.0001 \\
C & 0.277144 & 0.513227 & 0.540002 & 0.5919 \\
AR(1) & 0.383901 & 0.220864 & 1.738178 & 0.0890 \\
& & & & \\
R-squared & 0.858718 & Mean dependent var & 0.022765 \\
Adjusted R-squared & 0.846160 & S.D. dependent var & 0.133244 \\
S.E. of regression & 0.052261 & Akaike info criterion & -2.970476 \\
Sum squared resid & 0.122907 & Schwarz criterion & -2.779274 \\
Log likelihood & 79.26191 & Hannan-Quinn criter. & -2.897665 \\
F-statistic & 68.37804 & Durbin-Watson stat & 2.166429 \\
Prob(F-statistic) & 0.000000 & & \\
\hline
\end{tabular}

Source: own calculation using EViews

\section{Conclusions}

The minimum wage in the Czech Republic was established in 1991 and since then, the government has changed its amount 16 times. In the first years after the introduction of the minimum wage, the minimum wage was increased slower than the increase in the price level, and therefore the real minimum wage decreased. In the period 1999-2006 the government increased the minimum wage faster than the price level increase. Since 2007, however, due to the stagnation of the minimum wage, the real minimum wage has declined.
The purchasing power of the minimum wage was in addition to the price level also affected by adjustments of the rates of taxes and social and health insurance. As a result of these adjustments, the net minimum wage increased in some cases, even though the gross minimum wage stagnated. This was true especially in the case of the recipient of the minimum wage with a dependent child.

If the minimum wage is sufficiently higher than the living minimum, the minimum wage fulfils its motivational function. The analysis shows the net minimum wage has been lower than the living minimum in recent years in the case of a person with one dependent child. For 
these persons it is therefore more favourable to rely on social benefits than to seek a job. The same is also true for a person without dependent children who lives in a rental flat in Prague.

From the analysis it is clear that the relationship between changes of the minimum wage and changes in the unemployment rate in the Czech Republic is inconclusive. No statistically significant relation between unemployment dynamics and minimum wage could be found. To conclude, raising the minimum wage will probably have no negative effect on unemployment. This holds true for general unemployment but also for the unemployment of low educated and young people. On the contrary, our analysis has shown a clear effect of output growth on unemployment dynamics. We can see different reactions among selected groups as unemployment of young people seems to be quite sensitive to output growth. Also a significant dependency on lagged growth of unemployment was found. This can be explained by well-known problem of hysteresis on the labour market. It was discovered that people with lower education in particular tend to exhibit a higher tendency to hysteresis.

The article is one of the outputs from the research project "Flexibilita trhu práce České republiky" registered with the University of Economics, Prague under the number IGS MF/19/2012.

\section{References}

[1] BAŠTÝR̆, I. Porovnání úrovně, vývoje a postavení minimálních mezd a minimálních nákladů práce ve státech Evropské unie. Analýza statistických údajü. Praha: VÚPSV, 2007. ISBN 978-8087007-80-8.

[2] BAŠTÝR̆, I. Vybrané aktuální problémy uplatňování minimální mzdy v ČR. Praha: VÚPSV, 2005. [3] BROWN, C., GILROY, C., KOHEN, A. The Effect of the Minimum Wage on Employment and Unemployment. Journal of Economic Literature. 1982, Vol. 20, No. 2, pp. 487-528. ISSN 0022-0515.

[4] CARD, D., KRUEGER, A. B. Minimum Wage and Employment: A Case Study of the Fastfood Industry in New Jersey and Pennsylvania. American Economic Review. 1994, Vol. 84, No. 4, pp. 772-793. ISSN 0002-8282.
[5] CARD, D., KRUEGER, A. B. Myth and Measurement: The New Economics of the Minimum Wage. Princeton: Princeton University Press, 1995. ISBN 0-691-048231.

[6] FAILOVÁ, K., MYSíKOVÁ, M. The Minimum Wage: Labour Market Consequences in the Czech Republic. Finance a úvěr - Czech Journal of Economics and Finance. 2009, Vol. 59, No. 3, pp. 255-274. ISSN 0015-1920.

[7] FIALOVÁ, K. Minimální mzda: vývoj a ekonomické souvislosti v České republice. Charles University, 2007, No. 7. IES Working Paper.

[8] GOTTWALD, J., HANČLOVÁ, J., PYTLIKOVA, M. Minimum Wage and Its Impact on Wage Distribution, Unemployment and Hours Worked. In: GOTTWALD, J., et al. Determinants of individual pay and firms pay structures in the Czech Republics. Ostrava: VŠB-TU Ostrava, 2002. ISBN 80-248-0150-7.

[9] GREGG, P. The use of wage floors as policy tools. OECD Economic Studies no. 31 [online]. OECD, 2000 [cit. 2014-01-10]. pp. 133-146. (PDF). Available from: http://www.oecd.org/tax/ publicfinanceandfiscalpolicy/33709377.pdf.

[10] LEONARD, T.C. „More Merciful and Not Less Effective": Eugenics and American Economics in the Progressive Era. History of Political Economy. 2003, Vol. 35, No. 4, pp. 687-712. ISSN 0018-2702. [11] LESTER, R. A. Shortcomings of Marginal Analysis for Wage-Employment Problems. American Economic Review. 1946, Vol. 36, No. 1 pp. 63-82. ISSN 0002-8282.

[12] MINISTRY OF LABOUR AND SOCIAL AFFAIRS OF THE CZECH REPUBLIC. Minimální mzda [online]. Praha: MPSV, c2014 [cit. 2014-0110]. Available from: http://www.mpsv.cz/cs/870.

[13] NEDOMLELOVÁ, I. Milton Friedman: Remembrance of Personality and Economist. $E+M$ Ekonomie a Management. 2008, Vol. 11, Iss. 1, pp. 6-13. ISSN 1212-3609.

[14] NEUMARK, D., WASCHER, W. L. Minimum Wages. Massachusetts: The MIT Press, 2008. ISBN 978-0-262-14102-4.

[15] PAVELKA, T. The minimum wage in the Czech Republic - the instrument for motivation to work? In: 6th International Days of Statistics and Economics [online]. Melandrium, 2012 [cit. 2014-01-10]. 9 p. (PDF). Available from: http://msed.vse.cz/files/ 2012/Pavelka_2012.pdf. ISBN 978-80-86175-86-7. [16] SOUKUP, J., et al. Makroekonomie: Moderní přstup. Praha: Management Press, 2007. ISBN 978-80-7261-174-4. 


\section{Ekonomie}

[17] STIGLER, G.J. The Economics of Minimum Wage Legislation. American Economic Review. 1946, Vol. 36, No. 3, pp. 358-365. ISSN 0002-8282.

[18] VAUGHAN-WHITEHEAD, D. The minimum wage revisited in the enlarged $E U$. Geneva: International Labour Office, 2008. ISBN 978-92-2-121987.

[19] WEBB, S. The Economic Theory of a Legal Minimum Wage. The Journal of Political Economy. 1912, Vol. 20, No. 10, pp. 973-998. ISSN 0022-3808. [20] Zákon č. 262/2006 Sb., zákoník práce, ve znění pozdějších předpisů.

[21] Zákon č. 29/1920 Sb., zákon o úpravě pracovních a mzdových poměrů domácké práce.

[22] Zákon č. 76/1952 Sb, zákon o dani ze mzdy.

[23] ZDENĚK, R., STŘELEČEK, F. Hodnocení vývoje zaměstnanosti, průměrné mzdy a produktivity práce pomocí shift-share analýzy. $E+M$ Ekonomie a Management. 2012, Vol. 15, Iss. 3, pp. 4-15. ISSN 1212-3609. doc. Ing. Tomáš Pavelka, Ph.D. University of Economics, Prague Faculty of Business Administration

Department of Microeconomics pavelkat@vse.cz

Ing. Mgr. Marek Skála, Ph.D. Technical University of Liberec Faculty of Economics Department of Economics marek.skala@tul.cz

doc. Ing. Jan Čadil, Ph.D. Banking Institute Research Centre (BIRC) University of Economics, Prague Department of Economics jcadil @ bivs.cz 


\section{Abstract}

\section{SELECTED ISSUES OF THE MINIMUM WAGE IN THE CZECH REPUBLIC Tomáš Pavelka, Marek Skála, Jan Čadil}

The minimum wage is one of the measures of economic policy, which raises contradictory reactions. The Czech Republic is one of twenty EU Member States that have implemented a statutory minimum wage. Since its introduction in 1991, the gross minimum wage was increased sixteen times by the government. In addition to increases in the gross minimum wage, the purchasing power of the minimum wage is affected by the development of price levels and also by changes in tax and social security and health insurance. In the Czech Republic three periods in the development of the minimum wage can be distinguished. In the first years after its introduction, the gross minimum wage did not increase significantly and its real value declined. The period 1999-2006 is a period of rapid growth in both the nominal and the real minimum wage. In the period 2007-2012, the nominal wage was constant and its real value gradually decreased. These three phases correspond to the political orientation of Czech governments. Leftist governments raised minimum wages faster than right-wing governments. The article also provides an analysis of the motivational function of the minimum wage. It compares the net minimum wage with the living minimum. It appears that the motivational function of the minimum wage has been reducing in recent years. This is true especially for persons with dependent children. The last part of the article includes an analysis of the relationship between the increase in the minimum wage and the unemployment rate in the Czech Republic. In addition to total unemployment, the impact of the minimum wage on unemployment of young people and people with low levels of education is analyzed. It shows that there is no clear relationship between the minimum wage and the unemployment rates in the Czech Republic.

Key Words: Employment, minimum wage, unemployment.

JEL Classification: J31, J38.

DOI: 10.15240/tul/001/2014-4-003 